\title{
J(৫)
}

Received: 28.12 .2019

Accepted: 05.01.2020

Published: 29.01.2020

JOTS, 4/1, 2020: 280-282

\section{VÉR, M. Old Uyghur Documents Concerning the Postal System of the Mongol Empire, Berliner Turfantexte XLIII, Brepols Publishers, Turnhout (Belgium), 2019, 263 pp. ISBN: 978-2-503-58417-1}

\author{
Erdem UçAR \\ Prague/Czech Republic \\ E-mail: merdemu@gmail.com
}

Berliner Turfantexte serisinin 43. cildi olan eser, yazarın 2016 yllında Szeged üniversitesinde tamamladığı doktora tezine dayanmaktadır. Moğol dönemine (XIII.-XIV. yüzyıl) ait Uygurca posta teşkilatına ait belgelerin neşredildiği eser, Berliner Turfantexte serisi içinde dinî metinler dışındaki ilk neşir özelliğini taşımaktadır.

Eserin I. Introduction bölümünde Uygurlara ait posta teşkilatı ile ilgili olan Moğol dönemine ait belgeler hakkında bilgiler verilmiştir. (s. 11-55) Yazar, Eski Uygurcada posta teşkilatı ile ilgili olduğunu düşündüğü toplam 62 belge tespit etmiştir. Bu belgeler şunlardır: 1. Resmi belgeler (vergi hükümleri, kezig belgeleri, vs.); 2. Hesaplar; 3. Sicil kayıtları; 4. Şahsî kayıtlar. Yazar, Eski Uygurca sivil belgeler arasında metinde ulag, élçi, kupçir (< Moğolca) ve böz (< Yunanca) gibi 


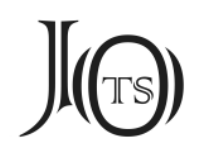

terimlerin geçmesine bakarak posta teşkilatına ait belgeleri bir araya getirmeyi başarmıştır, yani bu kelimeleri anahtar kavram olarak kabul etmiş ve bu anahtar kavramlara dayanarak korpusunu oluşturmuştur. Eserin giriş bölümünde Eski Uygurca belgeler ile Orta Moğolca belgeler de içerik ve yapıları bakımından birbiriyle mukayese edilmiştir (s. 40-44).

Yazarın tespit ettiği 62 adet posta teşkilatına ait belgenin büyük bir kısmı daha önce Raschmann 2007, 2009 ve Raschmann-Sertkaya 2016'da tavsif edilip kataloglamıştır. Ayrıca, bu belgeler daha önce birkaç kez çeşitli araştırmacılar tarafından (W. RADLOFF, L. TUGUŞEVA, D. MATSUI, vs.) neşredilmiştir. Yazar, kendi açılamalarıyla belgeleri yeniden neşretmiştir.

II. Editon of the Documents bölümünde (s. 59-197) Eski Uygurca belgelerin yazıçevrimi yapılıp açıklamalarla birlikte İngilizceye tercüme edilmiştir.

III. Appendices bölümünde (s. 201-229) neşrin dizini yer almaktadır. Eserin sonunda neşri yapılan belgelerin "metin tekabül listeleri” (concordence) verilmiştir. (s. 255-263)

Yazar, Moğol döneminde Uygurların posta teşkilatıyla ilgili olduğunu düşündüğü belgeleri tespit edip neşretmiş, posta teşkilatının XIII. ve XIV. yüzyıllardaki Uygurlar arasındaki önemini gözler önüne sermiştir. Moğol dönemi Uygurlarından kalan tarihî belgelerin neşri hem tarihçilere hem de filologlara şüphesiz faydalı olacaktır. Yazarı tebrik ederim.

\section{Kaynakça}

RaschmanN, S. Ch. (2007). Alttürkische Handschriften: Dokumente I, Verzeichnis der Orientalischen Handschriften in Deutschland (VOHD), Band 13/21, Stuttgart: Franz Steiner Verlag.

RaschmanN, S. Ch. (2009). Alttürkische Handschriften: Dokumente II, Verzeichnis der Orientalischen Handschriften in Deutschland (VOHD), Band 13/22, Stuttgart: Franz Steiner Verlag. 


\section{J(G)}

Raschmann, S. Ch. \& O. F. SeRTKAYA (2016). Alttürkische Handschriften, Alttürkische Texte aus der Berliner Turfansammlung im Nachlass Reșid Rahmeti ARAT, Verzeichnis der Orientalischen Handschriften in Deutschland (VOHD), Band 13/28, Stuttgart: Franz Steiner Verlag. 